\title{
0 gestus social em Rio Zona N orte: notas para um diálogo entre ator e diretor na análise cinematográfica
}

Luis Felipe Kojima Hirano ${ }^{1}$

Esse artigo procura interpretar o diálogo entre diretor e ator no filme Rio Zona Norte, dirigido por Nelson Pereira dos Santos e protagonizado por Grande Otelo. Ao propor essa interlocução, o artigo tem três objetivos: primeiro, o de apresentar um método de análise da performance do ator nos filmes de ficção, buscando observar de que modo Grande Otelo agrega sentidos ao personagem, ultrapassando os limites da montagem e enquadramento. Em segundo lugar, ao observar a interpretação de um ator negro, pretende-se examinar de que modo Grande Otelo e Nelson Pereira dos Santos se contrapõem aos estereótipos existentes no cinema de então. Por fim, após uma análise detida do filme, busco trazer elementos para compreender algumas das condições sociais que possibilitaram a Nelson Pereira dos Santos transformar o campo cinematográfico, propiciando, assim, um novo espaço de atuação para Grande Otelo.

Palavras-chave: Rio Zona Norte, Nelson Pereira dos Santos, Grande Otelo, performance do ator e estereótipo.

1 Bacharel em Ciências Sociais e Doutor em Antropologia Social pela Universidade de São Paulo. Em 2011, foi fellow da Universidade de Harvard. Atualmente, é professor adjunto da Faculdade de Ciências Sociais da Universidade Federal de Goiás e do Programa de Pós-Graduação em Antropologia Social da mesma instituição. Além disso, coordena a Coleção Antropologia Hoje da Editora Terceiro Nome e do Núcleo de Antropologia Urbana da USP. 


\section{The social gestus in Rio Zona N orte: an outline for the analysis of the dialogue between actor and director in films}

Abstract: this paper analyzes the dialogue between director and actor in the film Rio Zona Norte, directed by Nelson Pereira dos Santos and starring Grande Otelo. Through this dialogue, the article has three objectives: firstly, it presents a method for the assessment of the actor's performance in feature films, seeking to observe that Grande Otelo interpretations adds meaning to the character, beyond the limits established by the montage and camera frame. Secondly, by way of observing the interpretation of a black actor, the article intends to examine how Grande Otelo and Nelson Pereira dos Santos oppose to the existing stereotypes in the cinema by then, through the film. Finally, after a careful analysis of the film, I try to bring elements to understand some of the social conditions that allowed Nelson Pereira dos Santos to transform the cinematic field, thus allowing for a new performance space for Grande Otelo.

Keywords: Rio Zona Norte, Nelson Pereira dos Santos, Grande Otelo, actor's performance e stereotype.

é um gesto ou um conjunto de gestos (mas nunca uma gesticulação), onde se pode ler toda uma situação social Roland Barthes sobre o Gestus social (1990, p. 88).

O flashback é uma convenção deveras utilizada no cinema. Em geral, faz espectador e personagem voltarem ao passado, com vistas a pensar no presente de outra forma. É desse recurso que pretendo lançar no presente artigo, ao retrabalhar escritos de um passado recente, sobre um filme bastante comentado na 
cinematografia brasileira: Rio Zona Norte ${ }^{2}$. Das críticas da época às de Glauber Rocha (2003), da análise pormenorizada de Mariarosario Fabris (1994) aos recentes estudos que discutem a representação do negro no cinema, como o de Robert Stam (2008), Noel Carvalho e Carolinne Silva (2013), Rio Zona Norte já recebeu avaliações de diferentes olhares e perspectivas teóricas. Pretendo trazer mais contribuições para essas interpretações, mas a partir de uma outra perspectiva: procuro deslindar a performance de Grande Otelo, protagonista do filme, para refletir mais a fundo sobre este ator e o diretor Nelson Pereira dos Santos trabalham para desconstruir estereótipos em torno da população negra, rompendo com caracterizações correntes nos filmes realizados até então. Por sua performance, Grande Otelo fornece profundidade a seu personagem, o sambista Espírito; já o diretor consegue propor uma nova imagem do negro através da construção do roteiro, dos enquadramentos e da montagem.

Ao assumir tal ponto de partida, procuro agregar mais um nível às análises do estereótipo racial: para além do representativo, procuro visualizar a agência (BHABHA, 2007) dos atores negros frente aos papéis que lhe são fornecidos. Trata-se, assim, de um esforço para compreender quais são as estratégias e contribuições dos intérpretes afrodescedentes para se contraporem ao processo de estereotipia racial, fazendo frente a um mercado que reproduzia e reproduz assimetrias raciais na distribuição desigual e desproporcional de papéis entre intérpretes brancos e afrodescendentes ${ }^{3}$.

2 Esse artigo é uma versão modificada da primeira parte do capítulo 6 da minha tese de doutorado, disponível: http://www.teses.usp.br/teses/disponiveis/8/8134/tde14112013-122614/en.php

30 estereótipo é produzido por, ao menos, dois fatores: 1) pela a distribuição desigual e desproporcional de papéis entre brancos/as e negros/as; 2) pela repetição de algumas características exageradas, seja positiva ou negativamente. Assim, como explica Stuart Hall (1997) a população afrodescendente tem sido historicamente representada como extremamente preguiçosa/extremamente batalhadora, extremamente sensual/ extremamente feia, forte/fraca, etc. A mesma distribuição desigual, por sua vez, permi- 
Rio Zona Norte é, assim, um filme emblemático por combinar, por um lado, a interpretação excepcional de Grande Otelo, que dá vida aos dilemas e alegrias do personagem Espírito. Por outro, porque Nelson Pereira dos Santos abre espaço para que o ator exerça seu potencial dramático, subaproveitado na maioria de suas interpretações anteriores - por exemplo, nas chanchadas. Ao mesmo tempo, o longa é um marco na busca de princípios formais que expressam uma visão crítica do diretor frente à indústria fonográfica do Rio de Janeiro, o papel do intelectual e a exploração do compositor de sambas das periferias cariocas.

Divido o artigo em quatro partes. Na primeira faço uma discussão breve sobre a análise da performance dos atores no cinema - uma dimensão ainda pouco destacada nas investigações fílmicas. Em seguida, passo a um exame do filme e da atuação dos atores. Na terceira parte, adentro numa discussão sobre a trajetória social de Nelson Pereira dos Santos, a fim de compreender como as condições sociais do campo cinematográfico da época possibilitaram a realização de Rio Zona Norte. Por fim, discuto as críticas que o filme e Grande Otelo receberam.

tiu que o branco fosse representado de inúmeras maneiras, a ponto de tornar sua racialidade/cor invisível (DYER, 1997). Noutras palavras, o ator branco, quando atua, não representa sua raça, mas sim o homem universal. Já o intérprete negro ou negra tendem a ser vistos/as pelo público como alguém que representa não apenas o dilema de uma personagem qualquer, mas todo o seu grupo racial. Assim, seja qual for sua atitude, boa ou má, ela acaba sendo imediatamente associada a todos os negros e negras, como um processo metonímico conforme e fetichista (BHABHA, 2007). Por sua vez, o ator branco tem a liberdade de poder viver uma enorme variedade de papéis, desvinculados de sua raça/sexo - privilégio que mantém o poder desse ator frente a qualquer minoria, seja racial, de gênero, ou sexual. 


\section{O bservações sobre a performance do ator no cinema}

A perspectiva adotada nesse artigo muda a ênfase usual das análises sobre o cinema, ao abordar uma obra cinematográfica do ponto de vista do ator, em diálogo com o diretor, elenco, demais membros da equipe e seu público. Sendo assim, é necessária uma metodologia que acompanhe tal perspectiva, focalizando a contribuição do próprio intérprete em Rio, Zona Norte. Com isto em mente, detenho-me um pouco mais na discussão sobre o papel do ator no cinema.

Embora seja comum ver a crítica jornalística e os comentários do dia-a-dia avaliarem os filmes a partir da performance dos atores e atrizes, mais do que das opções de edição, enquadramento e direção, o reconhecimento acadêmico do papel dos intérpretes no cinema é recente. Na crítica acadêmica, tem prevalecido a tendência a favorecer o estudo da direção, analisando a montagem, enquadramento, fotografia e som. Os trabalhos que enfocam o artista/estrela costumam enfatizá-lo apenas como produto da indústria cinematográfica, sem qualquer margem de agência. Em parte, conforme as conclusões de Baron e Carnicke (2008), isso ocorre por conta do predomínio das investigações de cunho estruturalista, como as de Christian Metz, que concede pouquíssima importância ao ator na significação cinematográfica. 0 mesmo tende a ocorrer num tipo de análise que define o intérprete de cinema apenas pela falta de funções em relação ao teatro, como a de Walter Benjamin.

O debate é por demais complexo e cheio de meandros que extrapolam os objetivos deste artigo. Aqui, interessa apresentar argumentos que sustentem a hipótese de que um filme pode ser analisado também a partir da performance do ator. Para tanto, primeiro, discuto a importância do intérprete ao fornecer sentido à narrativa fílmica e, em seguida, exponho dados que descrevem a especificidade do trabalho do intérprete no cinema. 
Baron e Carnicke (2008) traçam uma genealogia dessa discussão, demonstrando como o próprio cineasta russo Lev Kuleshov, cujos experimentos ${ }^{4}$ foram utilizados como evidência científica de que apenas a montagem significava no cinema, reconheceria, em 1934, que o papel do ator era fundamental na linguagem cinematográfica. Ao comentar uma experiência pouco conhecida, realizada entre 1916 e 1917, ele descobriu que utilizando dois atores, um mais hábil que o outro, e intercalando cenas desses intérpretes numa mesma sequência de imagens, o resultado semântico era diferente. Kuleshov concluiu que, por meio da montagem clássica ${ }^{5}$, não é sempre possível alterar o trabalho semântico de um ator (KULESHOV, 1974, p.192).

No mesmo artigo, o autor reconhece a importância da performance do intérprete, condenando cineastas como Pudovkin, por terem perdido a habilidade de trabalhar com atores e darem demasiada ênfase à montagem clássica. Por fim, o realizador reconhece seu equívoco em trabalhos anteriores, quando deu um papel exclusivo à montagem no processo semântico do filme. Passava a entender que: quando uma ideia precisa ser expressada sobretudo no trabalho do ator, é necessário trabalhar em cima do ator [...]. Em nenhum caso, alguém pode assumir que todo o problema cinematográfico está na montagem. [...] a qualidade dos filmes nunca depende inteiramente na montagem (ibidem, p. 95). Convém lembrar que os primeiros experimentos de Kuleshov foram realizados num momento em que o cinema buscava afirmar

4 Refiro-me especificamente ao experimento que foi denominado de "Efeito Kuleshov", em que o diretor justapunha cenas com um mesmo rosto, sem expressão evidente, a objetos diferentes, tais como uma mulher no caixão, uma tigela de sopa e uma criança brincando. Cada uma dessas justaposições era lida pelos espectadores de modos diferentes: a primeira significava tristeza, a segunda fome e a terceira solidão. A conclusão de Kuleshov era de que os significados dessas cenas não eram tributários ao rosto, mas à montagem com outros objetos.

5 A definição de montagem é simples: trata-se de colar planos, ou seja, fragmentos de película, uns após os outros, numa ordem determinada. Confira, nesse sentido AUMONT e MARIE, 2003. 
sua singularidade como forma ${ }^{6}$ artística diversa do teatro, pintura e literatura, por meio da montagem clássica.

A ideia de montagem ganha outra dimensão nos escritos de Christian Metz (2010), para quem, grosso modo, o processo de significação no cinema ocorre pela identificação do espectador com o olhar da câmera, dentro de uma mesma cadeia discursiva. Tal perspectiva enfatiza apenas o sentido do filme a partir de seu encadeamento lógico, realizado pela edição, desconsiderando, como demonstram Baron e Carnicke (2008), que a seleção dos enquadramentos, montagem e duração das cenas, em muitos casos, é decorrentes das performances dos atores ${ }^{7}$. A correlação lógica da trama, portanto, não depende apenas da montagem, mas de uma incorporação dos gestos, de uma adequação da performance à estrutura do filme.

Tirante os complexos diagnósticos, insights e a identificação de possibilidades de encontrar um potencial revolucionário no cinema a partir do inconsciente óptico, Walter Benjamin define o intérprete de cinema pela sua ausência, quer de habilidades ao representar a si mesmo, quer por alienar-se de si no momento em que seu corpo se imprime em imagem, a ser exportada para qualquer lugar. Baseando-se em toda uma geração de teóricos que encontrou na montagem clássica a essência cinematográfica - como é o caso de Pirandello e Rudolf Arnheim -, Benjamin conclui que o ator nada mais é do que um acessório manipulado pela indústria de cinema ${ }^{8}$. 0 filósofo marxista morreria um ano

6 Forma, na acepção empregada no decorrer do artigo, significa: "princípio de organização da expressão em uma obra, em vista de um efeito de sentido ou afeto" (idem, p.134).

7 Baron e Carnicke, Reframing screen performance.

8 Tal análise é compreensível, considerando o momento em que o filósofo escreveu seu texto seminal; afinal, o nazismo recrudescia nesse período, fazendo uso dos aparatos cinematográficos como principal meio de estetizar a política. Ele próprio sofria perseguições por conta de sua origem judaica e daria fim à vida bastante melancólico com as possibilidades da arte num mundo em guerra. 
antes de ver posta em prática a radicalização no uso do plano-sequência ${ }^{9}$ empreendida por Orson Welles em Cidadão Kane (1941), que revolucionou o cinema.

Como analisa André Bazin, Welles, com formação no teatro, construiu a direção a partir do ator (BAZIN, 2006, p. 83-84). Diferentemente da decupagem tradicional ${ }^{10}$, o diretor estadunidense procurou privilegiar a profundidade de planos e longas sequências, em que os efeitos dramáticos são alcançados pelo desenrolar de uma cena contínua, que valoriza a interação entre os intérpretes e o cenário.

As longas-sequências e a profundidade de planos foram dilatadas com o Neo-Realismo italiano e, posteriormente, com a Nouvelle Vague e o Cinema Novo, produzindo, nos termos de Bazin, um abalo sísmico na linguagem cinematográfica e conformando as principais características do assim chamado cinema moderno. Toda essa transformação traz um novo calibre para o intérprete de cinema, exigindo dele uma atuação mais contínua, atenta aos diferentes elementos da cena, e ajustando seus diversos movimentos em um mesmo enquadramento da câmera. Como veremos a seguir, Rio, Zona Norte se nutre dessa transformação, especialmente pelo diálogo que trava com Neo-Realismo italiano.

Se com essas transformações, ainda é verdade que o ator de cinema representa a si mesmo, como afirmou Walter Benjamin, isso não significa que a exigência seja menor quanto à habilidade do intérprete cinematográfico. Os processos de incorpora-

9 Trata-se de "um plano bastante longo e articulado para representar o equivalente de uma sequência [uma cena]” (AUMONT e MARIE, 2003, p. 231).

10 Tipo de encadeamento lógico dos sentidos do filme, largamente utilizado no cinema silencioso, que se baseia exclusivamente nas sequências curtas da montagem clássica. A atuação dos atores era toda dividida em diferentes tomadas para depois ganhar sentido na sala de edição. Welles, explorando a tecnologia sonora, faria o inverso: o sentido do filme viria principalmente da ação do ator em cena - daí, os longos planos-sequência. A edição teria o papel de enfatizar essa ação. 
ção dos personagens, tanto no cinema, quanto no teatro exigem habilidades específicas, como a personalização mais constante, no caso do primeiro, e a despersonalização, no caso do segundo (MCDONALD, 2008). Entretanto, nem sempre um ator consegue personalizar um personagem. Tal procedimento se torna mais explícito nas adaptações literárias para o cinema. Geralmente, o que ocorre é uma incongruência entre a imaginação que criamos em torno do personagem do livro e o intérprete. São raros os casos em que o ator se cola de tal modo ao personagem que, depois de ver o filme, não conseguimos imaginar nenhuma outra figura quando voltamos a folhear o livro. É o que ocorre com Grande Otelo, quando personifica Macunaíma. Basta dizer que o efeito assemelhado não ocorre quando Paulo José interpreta o mesmo personagem, em sua fase branca.

Há ainda outras diferenças que explicitam a especificidade do intérprete de cinema. Em primeiro lugar, se o movimento da câmera, por um ângulo, seleciona, por outro, possibilita um olhar mais atento do espectador a cada detalhe da expressão facial, da força utilizada na musculatura e das veias saltadas, entre outros aspectos que, dependendo da distância que se está do palco, são imperceptíveis para a plateia de teatro. Em segundo lugar, a descontinuidade da produção cinematográfica costuma demandar do ator a capacidade de imaginar a totalidade, para conferir expressividade ao mínimo detalhe captado pela câmera e redimensionado na tela de cinema. Tal habilidade de mapear o todo também é necessária quando o intérprete filma a cena sem a presença dos outros atores que compõem a mesma sequência ${ }^{11}$.

Em terceiro lugar, as opções de movimento precisam caber milimetricamente no enquadramento do diretor, assim como é importante o meneio na medida correta para que seu redimen-

11 É verdade que alguns diretores usam como tática o desconhecimento do ator no desenrolar da trama, nesse sentido, nem sempre é exigido ao ator o mapeamento geral da trama. 
sionamento na écran mantenha o ritmo e o volume que a cena requer. Por mais que o diretor descreva sentimentos, desejos, emoções e a alma do personagem, seja com palavras ou gestos, cabe apenas ao ator interpretar e incorporar tais elementos a seu corpo para dar vida ao papel, como ensinava em seu manual Josephine Dillon, professora de técnica de atuação na chamada Era dos Estúdios de Hollywood: as lentes das câmeras e as lentes dos olhos humanos veem apenas o corpo e o vestuário exterior do ator, não veem o seu pensamento, a sua emoção, as suas esperanças e sonhos (DILLON, 1940, p. 55).

Por fim, a estrutura de poder da produção de um filme não é estática. 0 ator pode valer-se de espaços exíguos para ganhar proeminência em uma cena, chegando por vezes a conseguir abertura para dar palpites no enquadramento e iluminação, entre outros aspectos ${ }^{12}$. Grande Otelo, por exemplo, conseguia sugerir cenas e colocar composições de sua autoria nos filmes do diretor José Carlos Burle; já com Watson Macedo, o diálogo era mais difícil. Oscarito tinha tal autonomia na Atlântida, que conseguiu expulsar José Carlos Burle da empresa, pois ele não quis filmar uma cena cômica em close-up. 0 ator continuou e a cena foi refeita para atender seu pedido (AUGUSTO, 2005). Ruth de Souza conhecia todas as técnicas de direção e iluminação teatral e cinematográfica, aprendidas em seus estágios nas universidades de Ohio, Howard e Washington, o que lhe permitia reconhecer os momentos em que a iluminação contribuía para lhe dar destaque no palco e na tela (SOUZA, 1979). Fred Astaire tinha tal poder na estrutura cinematográfica, que escolhia os enquadramentos e editava suas cenas de dança. Com isso, é reconhecido por ter criado um estilo intimista de musical, diverso dos números caleidoscópicos de Busby Berkeley. Como será discutido a seguir, Nelson Pereira dos Santos, ape-

12 Não se trata de desconsiderar o frequente desnível de poder entre o realizador e o ator, mas de reconhecer que nos meandros da direção de ator, há uma margem de ação do intérprete para incorporar em gestos os objetivos do diretor. 
sar dos parcos recursos que tinha à sua disposição, dialogava bastante com seus atores.

Se os principais argumentos a favor de uma análise da performance do ator no cinema estão claros, importa, agora, introduzir meios e formas de como mapear os gestos, as expressões faciais, o direcionamento do olhar, a impostação da voz. Conforme Baron e Carnick (2008), a verossimilhança de uma interpretação se constitui no uso da musculatura corporal e da voz num ritmo, frequência, fluxo e força que dão materialidade precisa aos conflitos do enredo dentro dos limites do aparato cinematográfico. Nesse sentido, há que atentar para 1) o uso do espaço do ator no enquadramento da cena; 2) o tempo: a velocidade e o ritmo dos gestos numa sequência fílmica; e 3) o peso e a força no uso do corpo, na contração e relaxamento da musculatura. Tais procedimentos corporais de uso do espaço e do tempo sinalizam o modo como o ator incorpora o enredo, revelando nas minúcias dos gestos os conflitos pessoais do personagem no filme.

Além disso, as técnicas de atuação devem ser vistas em diálogo com tradições como as de Stanislavsky e Brecht, que foram adotadas nas correntes e gêneros cinematográficos ao longo do século $\mathrm{XX}^{13}$. Atentar para as convenções, tanto de técnicas de interpretação, quanto dos movimentos e gêneros cinematográficos é fundamental, pois elas dão pesos diferentes ao trabalho de ator. Rio, Zona Norte, nessa perspectiva, é um filme interessante de ser analisado, justamente pelo jogo câmera-ator empreendido por Nelson Pereira dos Santos e pela atuação singular de Grande Otelo, bem recebida pela crítica da época e por análises posteriores.

13 Vide as análises de Baron e Carnick (2008) de Romeu e Julieta em épocas distintas, mostrando as diferenças nas interpretações dos atores. Na análise do filme Os sete samurais, de Kurosawa, e a adaptação do mesmo roteiro para faroeste americano em The Magnificent Seven, ficam patentes as diferenças culturais na aprendizagem e nos significados das expressões - no filme de Kurosawa, é marcante a utilização de expressões do teatro Nô e a movimentação de palco do teatro de bonecos do Kabuki, diferentemente da adaptação americana. Baron e Carnicke, Reframing screen performance. 


\section{0 diálogo ator-câmera em Rio, Zona Norte}

Ao som de um pout-pourri alegre, que caminha para um tom melodioso, a câmera em plongée enquadra a Avenida Presidente Vargas, com carros e transeuntes passando. Surgem os primeiros créditos: Nelson Pereira dos Santos apresenta: Grande Otelo em Rio, Zona Norte. Em leve movimento para direita descortina-se a Praça Major Valô e, em seguida, um contra-plongée dirigido para o alto deixa ver a torre da Estação Central do Brasil. Primeiro corte. De cima para baixo, dentro do terminal, a filmadora registra passageiros enfileirados, comprando bilhetes. Segundo corte. Do vagão, as lentes cinematografam diferentes feições de trabalhadores na plataforma, esperando o próximo veículo em direção aos subúrbios da assim chamada "cidade maravilhosa". Terceiro corte. Da janela do trem em movimento, avistam-se casebres simples e construções decadentes, próximas ao Morro da Providência. Quarto corte. Na Avenida Francisco Bicalho, atravessada por um córrego pavimentado e ladeada por coqueiros, os créditos retornam. Jece Valadão, Paulo Goulart, Maria Petar... aparecem escritos por sobre imagens de favelas e pequenas indústrias nas encostas da ferrovia.

Quinto corte. Um vagão cruza o caminho e, logo depois, um homem branco com certa idade, portando camisa amassada e desabotoada - provavelmente um morador de rua - salta os trilhos, aproximando-se das lentes da câmera, e agacha para ajudar um homem negro, caído de frente para o chão. Outros dois brancos, mais bem vestidos, chegam para olhar. 0 primeiro explica o que aconteceu; um deles vai embora, o outro tenta ir, mas é segurado pelo braço. Enquanto isso, um negro chega correndo e ajuda a carregar o acidentado. Num esforço entre os três, o levantam. Descortina-se o rosto do ator Grande Otelo, desacordado. Enquanto a vítima é levada para longe dos trilhos, a câmera focaliza um amontoado de papéis amassados. 0 que parecia ser o morador de rua pega o almaço e retorna para ver o agonizado. 0 rosto de Otelo ocupa quase a totalidade do quadro. Ele mexe 
o pescoço vagarosamente e, aos poucos, abre os olhos, ainda inconsciente. 0 som de um trem passando é sobreposto ao "som subjetivo" de um tamborim, um pandeiro e, em seguida, a um coro de sambistas. 0 samba antecede o próximo corte: em câmera subjetiva, através das lembranças de Otelo, focaliza-se o ator dando uma gargalhada gostosa, quando seu Figueiredo chama Espírito, nome de seu personagem, para animar a festa.

Esses são os primeiros minutos de Rio, Zona Norte, de Nelson Pereira dos Santos. A partir dessas cenas, o filme intercala o flashback de Espírito e as sequências em que se desenrola seu socorro. A câmera subjetiva, na altura dos olhos de Grande Otelo, mormente em contra-plongée, medeia as imagens na perspectiva de Espírito, que vê o mundo que o rodeia de baixo para cima. Suas reminiscências começam numa noite de festa no morro, na Escola de Samba Unidos da Laguna. Animado, ele canta Mexi com ela, composição de sua autoria que chama a atenção de Maurício (Jece Valadão), um compositor, e Moacyr (Paulo Goulart), um violinista, ambos da mesma emissora de rádio. 0 primeiro, Espírito já conhece, pois com ele tentara lançar algumas músicas, sem êxito, ao passo que o segundo, não. Moacyr, de formação erudita, diz que sonha criar um balé com sambas "autênticos", mas que, para se sustentar, vende seus vinte anos de estudo, dedicando-se ao acompanhamento de arranjos genéricos das paradas de sucesso.

Tanto Maurício, quanto Moacyr convidam Espírito para conversar na emissora de rádio - o primeiro quer emplacar Mexi com ela e o segundo, pensar numa parceria com o compositor. A proposta reacende os sonhos de Espírito e de seus membros diletos da comunidade, como a afilhada Gracinda, o compadre Honório, e Figueiredo, o dono da vendinha onde o sambista faz "biscates". Porém, mais do que desfrutar o sucesso de seus partidos-altos sendo entoados pela diva do rádio, Ângela Maria, Espírito também pretende utilizar o dinheiro da venda das canções para terminar de construir uma casa própria e um armazém, em con- 
junto com Honório, para ter estabilidade e conseguir de volta a guarda do filho, Norival. Na mesma noite, o sambista cai nas graças de Adelaide (Malu), uma negra de pele clara, empregada doméstica que passa a morar com ele, trazendo junto seu bebê. A união dos dois e o apego a uma criança pequena reacendem as expectativas de Espírito de constituir uma nova família e reescrever de outro modo a sua história.

Na emissora de rádio, Espírito encontra Moacyr. A conversa entre os dois é interrompida pela esposa do violinista e eles marcam de conversar em outra ocasião. 0 sambista também encontra Maurício, que se mostra preocupado com a intromissão do músico na relação entre os dois. Maurício então o apresenta ao cantor negro Alaor da Costa (Zé Kétti) e propõe uma parceria a três como condição para lançar Mexi com ela. Espírito não se mostra feliz com a ideia de dividir sua própria composição, mas acaba aceitando em troca de dinheiro, pois se encontra numa situação financeira instável e precária. É então convencido a tentar emplacar no mercado fonográfico com esse samba, antes de tentar o sucesso individual.

Na festa de batismo do filho de Adelaide, os convidados sintonizam a emissora e ouvem felizes Mexi com ela, na voz de Alaor da Costa. Mas, para o espanto de todos, quando a música termina Espírito não é creditado - Maurício e o cantor são os únicos autores citados pelo locutor. Ademais, como nota o sambista, Alaor deturpou o ritmo do partido-alto para um bolero. Gracinda, Figueiredo e o compadre revoltam-se e incentivam Espírito a protestar na rádio. Adelaide, decepcionada com o novo companheiro, com quem esperava ascender socialmente, o critica porque não tem "nem dinheiro, nem gaita".

A trama se inverte e os sonhos de Espírito caminham para a tragédia. Sua relação com Adelaide estremece, ainda mais com o retorno inesperado de Norival, que logo na chegada rouba a venda de Figueiredo. Para piorar a situação, o compositor precisa ceder 
às pressas sua casa, quase pronta, aos irmãos de Honório, que foram desalojados. Adelaide vai embora. Maurício enrola mais uma vez Espírito e, em troca de dinheiro, consegue que o sambista assine um termo que retira sua autoria de Mexi com ela. Ao voltar para casa sem os direitos pelo samba, é surpreendido com partida de Adelaide e por um bando de moleques que assassina Norival por vingança. Diante da morte do filho, apenas a criação do samba Fechou o paletó consegue dar-lhe alento e força para continuar a busca de reescrever sua história, como se os versos e refrãos lhe servissem de projetor aos sonhos futuros. Maurício vai ao enterro para convencer Espírito a assinar outros termos e logo se interessa pela música, mas dessa vez Espírito se revolta, o derruba e diz: "não, Maurício! Esse samba... esse samba é só meu, eu vou gravar ele sozinho e há de ser com a Ângela Maria!”.

No dia seguinte, Espírito encontra a cantora dando autógrafos aos fãs na emissora de rádio e cria coragem para falar com a diva, que interpreta seu samba com grande entusiasmo e interesse. Numa das cenas mais emblemáticas do filme, começa a cantar e batucar Fechou o paletó numa caixa de fósforo, enquanto ela escuta, tomando café. Num jogo de olhares entre Ângela Maria e Espírito, em campo-contracampo ${ }^{14}$, plongée e contra-plongée, e em plano aberto mostrando os fãs ao redor da dupla, a cantora aos poucos se deixa envolver pela música, ouvindo o sambista e lendo a letra no papel amassado que ele lhe entregara. Ela mexe a cabeça e os ombros em ritmo de partido-alto, chega um violonista na hora, compõe-se o arranjo. Espírito cresce em sua interpretação, a cada verso, na mesma proporção que os fãs da diva, que estão a sua volta, também se animam. A câmera fecha no rosto de Espírito outra vez e ouvimos a voz de Ângela Maria cantar o verso e o refrão: "céu estrelado, lua prateada, muitos sam-

14 É uma técnica de filmagem usualmente utilizada em diálogos entre personagens. Conforme Aumont e Marie (2003, p. 62), o 'contracampo' é uma figura de decupagem que supõe uma alternância com um primeiro plano então chamado de 'campo'. 0 ponto de vista adotado no contracampo é inverso daquele adotado no plano precedente, e a figura formada dos dois planos sucessivos é chamada de 'campo-contracampo'. 
bas, grande batucada, o morro estava em festa quando alguém caiu, com a mão no coração sorriu, morreu Malvadeza Durão, o criminoso ninguém viu". Numa montagem vertical, que justapõe som e imagem, ouve-se Ângela Maria cantando, e sua voz contraposta ao rosto de Espírito, que modula a sua alegria abrindo o sorriso na cadência do samba, seus olhos, sobrancelhas, a musculatura da testa e todo o seu corpo movem-se no ritmo da canção expressando a satisfação por vislumbrar que seu sonho voltava a se realizar. Nota-se, que em toda essa sequência Grande Otelo quase não pisca, olhando para Ângela Maria, balanceando suas pupilas e enfatizando os termos da letra da música ${ }^{15}$.

Ângela Maria considera a composição "fabulosa" e pede para Espírito trazer a música em partitura de piano. Desprovido de meios para transpor seu conhecimento para a pauta musical, Espírito vai à casa de Moacyr, para pedir-lhe ajuda. 0 violinista recebe-o de maneira entusiasmada e o apresenta a três amigos intelectuais como "o maior sambista vivo". Espírito dá uma canja com Fechou o paletó, que eles apreciam, com olhares analíticos e sem ceder os seus gestos ao som, mantendo as mãos cerradas entre si. Logo, começam a discutir a característica estética da música e a possibilidade de fazer um balé com suas composições, sem "estilização". Chega uma amiga de Moacyr, revoltada com a montagem de uma peça teatral, e os intelectuais esquecem do samba. Espírito, deslocado na conversa, no canto do sofá, resolve partir. Moacyr vai atrás dele e pede que volte outro dia para escrever a partitura do samba.

Em direção à Central do Brasil, Espírito pega o trem de volta para a zona norte. As mesmas cenas que iniciam o filme de dentro do vagão são repetidas, mas agora intercaladas com a imagem de Espírito, que compõe um outro samba a partir da conversa que ouviu dos passageiros. A intenção de Nelson Pereira dos Santos

15 Manter os olhos abertos em toda uma sequência em close é uma estratégia dos atores e atrizes justamente porque isso fortalece a atenção do espectador no ator (BORDWELL, 2013). 
nessa sequência é convidar o espectador, agora ciente da história de Espírito, a rever as mesmas cenas, na perspectiva do compositor, que viaja pendurado na porta do trem lotado, até que cai nos trilhos. 0 flashback fecha o ciclo e voltamos ao registro do presente: em câmera subjetiva, vemos Moacyr e Honório observando se Espírito dá algum sinal de vida após a operação de emergência para salvá-lo. São os últimos sinais do sambista, que sucumbe.

Na última cena do filme, Moacyr e Honório caminham cabisbaixos numa rua escura. Moacyr levanta a cabeça abre a boca e fecha, hesita e pergunta: "você conhece os sambas do Espírito?". Honório diz: "um pouco [...] se você quiser podemos ir lá no morro muita gente conhece alguns sambas de Espírito". "Alguns..."; "uns três ou quatro, os melhores".

Se nas chanchadas o uso da justaposição entre campo e contracampo, câmera objetiva e subjetiva é escasso, utilizado apenas na troca de olhares entre casais apaixonados, ou para introduzir um número musical, em Rio, Zona Norte tais recursos são centrais e aplicados de modo radical para coligir visões e posições diferentes entre as personagens. Nesse jogo dialógico, inclui-se o espectador, que é convidado a ver em vários momentos a realidade na altura dos olhos de Espírito, em contra-plongée, e na altura daqueles que o veem - como Maurício, Moacyr e Ângela Maria, entre outros personagens mais altos -, em plongée. No cinema clássico, esses enquadramentos de baixo para cima são empregados para engrandecer e o de cima para baixo, para diminuir. Nelson Pereira dos Santos vale-se desse mecanismo para destacar as desigualdades sociais entre as personagens: aqueles que detêm os meios para estabelecer-se nas emissoras de rádio e o sambista do morro, destituído de capital simbólico, social e cultural para tanto.

Como analisa Mariarosaria Fabris (1994), o contra-plongée e o plongée são articulados, em Rio, Zona Norte, respectivamente às câmeras subjetiva e objetiva. 0 uso alternado desses recursos se desvelaria um nível narrativo em que Nelson Pereira discute a 
relação entre uma História oficial e uma história subterrânea da população das periferias do Rio de Janeiro, no quadrante norte da cidade (FABRIS, 1994, p. 190). Por um lado, a câmera objetiva que olha Espírito do alto e narra o enredo no tempo presente, isto é, no desenrolar do socorro do sambista, mostra a cada sequência como aqueles que o auxiliam - do morador de rua ao policial e os médicos - o veem como um "pingente", "sem nome e documento" (nos termos do próprio filme). Por outro, o flashback inicia-se com a câmera subjetiva, de baixo, que transforma o "pingente" em "pessoa" (DA MATTA, 1997), com identidade e uma rede de relações. Noutros termos, Nelson Pereira dos Santos lança mão dos princípios formais para contrastar a História com "h" maiúsculo, que resume-se aos registros de óbito do Estado e manchetes de jornais, que dizem: "um pingente morre nos trilhos do trem". O contraste é mobilizado por meio daquilo que Fabris denomina "história subterrânea", ou seja, a história do ponto de vista de um compositor, portador de uma "cultura autêntica e sem estilização", segundo o filme.

Os planos de conjunto, quando Espírito está entre Moacyr e sua esposa ou amigos, sinalizam, no meneio de cada intérprete, proximidades e distanciamentos, o olhar de aprovação, de desdém e a contemplação analítica da classe média em relação ao sambista do morro. Há todo um jogo nos enquadramentos, que articulam uma visão de estrutura social internalizada na forma do filme e na interpretação dos atores. Os close-ups em Espírito não são apenas um meio de colocar o personagem no centro da narrativa, mas um espaço aberto para que, a partir do seu gestual, Grande Otelo expresse todo conflito social inscrito em seu personagem.

Grande Otelo aproveita ao máximo esse espaço, ao cadenciar com cuidado toda a série de emoções de seu personagem no decorrer do filme: alegria, seriedade, paixão, tristeza, alívio e tensão, encarnados no retesar de sua musculatura, no movimentar pesado dos braços em momentos dramáticos e na soltura de seus gestos em situações de conforto e felicidade. 
Os enquadramentos abrem espaço para que Grande Otelo exercite sua verve dramática, pouco comum nos filmes em sua trajetória até então. Dos títulos que encenou antes de Rio Zona Norte, conta-se nos dedos de uma mão aqueles que permitiram um grau similar de expressão dramática ao ator: Moleque Tião (1943), Também somos irmãos (1949) e Dupla do barulho $(1953)^{16}$, os dois primeiros dirigidos por José Carlos Burle e o último por Carlos Manga. É, pois, no interstício do diálogo cineasta-intérprete, que Nelson Pereira dos Santos se revela um grande diretor de atores e que Grande Otelo expõe sua atuação singular, fazendo jus ao parco espaço que o campo cinematográfico lhe forneceu para interpretar um papel de modo a extrapolar aquilo que se esperava para os atores negros.

É conhecido e evidente o diálogo entre as primeiras produções de Nelson Pereira e o Neo-Realismo italiano. Note-se que, antes de Rio, Zona Norte, o cineasta foi criticado por Rio, 40 graus (1955): para Alex Viany, ele teria negligenciado a tradição cinematográfica local, como mostra Fabris (1994). É importante perceber que mesmo Roma, cidade aberta (1945), de Roberto Rossellini, obra inaugural do Neo-Realismo, ligava-se à cultura popular italiana ao escalar Anna Magnani e Aldo Fabrizi, ambos artistas renomados no teatro de variedades e em filmes de sucesso nos anos 1930 e 1940 (idem, ibidem). Logo, em reação à critica, em Rio, Zona Norte o diretor procura conectar-se também à produção realizada no Brasil de então, ou seja, as chanchadas e o Realismo Carioca de Alex Viany, Alinor Azevedo e Burle (idem, ibidem). A eleição de Grande Otelo como ator principal, a trama com números musicais e o fato de uma das locações ser uma emissora de rádio, apontam para uma conversa manifesta com a produção carioca anterior.

No entanto, Rio, Zona Norte produz uma referência radicalmente crítica à chanchada e à indústria fonográfica que a sustenta. De 
modo similar ao que ocorre em Abismo de um sonho, de Fellini (1952), em que uma fã se desilude com seu herói de fotonovelas quando tem a chance de conhecê-lo pessoalmente, Nelson Pereira dos Santos faz uso das cenas musicais e da rádio para mostrar sua dimensão ideológica no sentido marxista: busca produzir uma imagem condizente com a realidade dos meios de produção. Nesses termos, o mito do sucesso inesperado das pessoas das classes baixas, construído pelas rádios e pelas chanchadas, revela sua faceta mais dura em Rio, Zona Norte: mesmo que talentoso, Espírito não dispõe dos meios e capital necessários para emplacar suas composições e, por isso, é espoliado até a desintegração total de sua família e sua própria morte trágica. Se nas chanchadas as personagens de Grande Otelo logravam êxito via golpes de sorte e malandragens, agora acontecia o inverso: mais do que mostrar o precipício de um sonho, Nelson Pereira dos Santos declara o fim iminente do "samba autêntico". Na voz lacônica de Honório, emerge ao final a referência a apenas "três ou quatro sambas" de Espírito conhecidos no morro. Espírito, aliás, é avesso à malandragem e aos golpes de sorte, de modo que estes não se apresentam como meios viáveis para alguém como ele.

Em termos musicais, há uma contraposição entre o samba de partido-alto, criado nos morros, tendo como instrumento principal as caixas de fósforos, e os arranjos orquestrados das rádios, que transformavam composições como Mexi com ela em boleros. Em tempos anteriores, Orson Welles buscara explorar o mesmo tipo de contraste em It's all true, com vistas a mostrar a diversidade do carnaval, mas também as segregações existentes (BENAMOU, 2007; STAM, 2008; HIRANO, 2013a). No entanto, em Rio, Zona Norte a oposição entre um tipo de arranjo e outro ganhava sentido dialético, tornando-se uma formalização sonora para as lutas de classe.

Nelson Pereira dos Santos não se contentou em fazer um retrato esquemático da sociedade, descarnado de qualquer relação visceral. Ele baseou todo o argumento e o roteiro do filme em 
longas conversas com Zé Ketti, amigo desde as filmagens de Rio, 40 graus, com quem dividia o apartamento na época. Foi o sambista quem lhe comentou o sistema de venda de canções. Além disso, o diretor viveu no morro durante alguns meses a fim de melhor captar as particularidades daquele contexto para o filme (SALEM, 1987).

Penso que Rio, Zona Norte compõe de maneira complexa a intersecção entre raça e classe. Não se trata apenas de uma representação do negro como povo bom, generoso e ingênuo ${ }^{17}$, pois em todas as classes retratadas, há personagens bons e maus, lineares e multidimensionais.

Espírito é talentoso e de boa índole. No decorrer da trama, é ludibriado por Maurício, mas desenvolve uma consciência da exploração, muda de estratégia e consegue, por conta própria, apresentar sua canção a Ângela Maria. Dessa maneira, o personagem é distinto daqueles vividos pelo ator nas chanchadas, mais próximos da definição de malandro de Antonio Candido: tipos esvaziados de lastro psicológico, caracterizados apenas pelos solavancos do enredo (CANDIDO, 1993, p. 23), oscilando entre a ordem e a desordem. Em Rio, Zona Norte, são as experiências da vida que agregam novas características à personagem.

A película também faz outro uso da dimensão corporal de Otelo, diferente daquela empregada pelas chanchadas: a baixa estatura e o rosto arredondado, mostrados com frequência em primeiro plano, favorecem a identificação e certa comiseração do público com relação a Espírito. Tais predicados não são empregados para infantilizá-lo, pois a composição de seu personagem é cercada de elementos que lhe dão integridade e maturidade: Espírito não é apenas pai, mas também padrinho, preocupa-se com o destino do filho e faz companhia para a afilhada, Gracinda. Como notou Robert Stam (2008), é quase inexistente a figura do pai

17 Vide, a tal respeito, Carvalho, 2005. 
negro nos filmes hollywoodianos e brasileiros. A construção de um personagem complexo também se expressa no projeto de vida de Espírito: ele pretende ter uma casa e negócio próprio para conseguir a tão esperada guarda do filho, de modo que o sucesso de seus sambas significa mais um meio para a realização de um sonho factível.

A construção do filme expressa um modelo de estrutura social em que Espírito tem pouca margem de negociação, destituído de capital social e econômico o compositor é quase obrigado a entregar seus sambas a Maurício. Tal construção contudo, não retira a margem de agência da personagem, que reluta em dividir suas canções - o que só aceita fazer mediante as pressões financeiras. Mais do que ingenuidade, ou ausência de característica psíquica fixa, é a própria desigualdade social que obriga o sambista a tomar tal atitude.

O cantor Alaor da Costa é o simétrico inverso de Espírito. Ambos são negros, de tez escura, mas o primeiro se integra à indústria cultural e, em parceria com Maurício (de pele clara), rouba os sambas do compositor do morro. Quando Espírito entra em seu camarim, Alaor sequer estende a mão para ele. Ao mostrar dois personagens da mesma cor, em posições tão diferentes na estrutura de classes e no campo cultural, Nelson Pereira dos Santos enriquece seu retrato realista, despojando-o de essencialismos, estereotipia racial e evitando relações metonímicas entre cor e índole dos personagens.

Igualmente, os moradores da assim chamada Zona Norte se distinguem tanto nas características étnico-raciais quanto nos valores morais. Honório, Gracinda e Figueiredo são brancos e todos solidários entre si. A esposa de Figueiredo e Adelaide são pardas. A primeira, generosa; a segunda, interesseira. Norival e o filho de Adelaide são negros. No bando que assassina o filho de Espírito, há um menino branco, um negro e um pardo. Além de matarem gente da própria classe social, eles roubam Espírito. Não há, por- 
tanto, apenas um retrato condescendente do povo: há conflitos e disputas internas, que solapam o próprio estrato econômico.

Assim, se há um certo determinismo no longa-metragem, ela se escora na estrutura de classes. Mas tal procedimento não se desenvolve de forma caricatural. Entre aqueles que trabalham na rádio, há os de má índole, Alaor e Maurício, mas também os de boas intenções, como Maurício e Ângela Maria. No entanto, Nelson Pereira dos Santos critica o paternalismo do violinista e da diva do rádio com relação a Espírito. De acordo com o filme, ambos procuram ajudar o sambista, mas não conseguem despojar-se da própria posição de classe e ver as reais condições do compositor. Moacyr, por exemplo, pergunta qual o seu telefone, mas não percebe que esse é um bem material escasso na periferia, que ele não possui; e o convida para passar na rádio e em sua residência, mas tampouco nota que o preço do deslocamento da Zona Norte para a região central custa um dia de trabalho do sambista. Ângela Maria, por sua vez, entusiasma-se com Fechou o paletó, mas é incapaz de perceber que Espírito não tem meios para transpor sua música para a partitura. Assim, ninguém se salva na pequena burguesia de Rio, Zona Norte. Entre o povo, apesar das gangues, há formas solidariedades inexistentes nas classes média e alta.

O desenho da estratificação social no longa-metragem de Nelson Pereira mostra aquilo que Marcelo Ridenti identifica nas manifestações de esquerda, em meados da década de 1950 e nos anos 1960 e 1970, a saber, um romantismo revolucionário. Conforme o sociólogo, o romantismo seria uma visão de mundo ampla, uma resposta a essa transformação mais lenta e profunda - de ordem econômica e social - que é o advento do capitalismo (RIDENTI, 2000, p. 26). Já o romantismo de esquerda seria revolucionário, pois era modernizador:

Ele buscava no passado elementos para a construção da utopia do futuro. Não era, pois, um romantismo no sentido da perspectiva anticapitalista prisioneira do passado, geradora 
de uma utopia irrealizável na prática. Tratava-se de romantismo, sim, mas revolucionário. De fato, visava-se resgatar um encantamento da vida, uma comunidade inspirada no homem do povo, cuja essência estaria no espírito do camponês e do migrante favelado a trabalhar nas cidades - como fica claro nas palavras do cineasta Nelson Pereira dos Santos: 'Naquela época, a favela era um ambiente semi-rural. Você pode reparar no filme [Rio, Zona Norte] que todas as casas têm um espaço, não estão grudadas umas nas outras. A maioria das casas tinha um quintal, com alguma criação, uma hortaliça. As pessoas estavam reproduzindo condições de existência que tinham no campo, fora da cidade. [...] Não se tratava de propor a mera condenação moral das cidades e a volta ao campo, mas sim de pensar - com base na ação revolucionária a partir do campo - a superação da modernidade capitalista cristalizada nas cidades, tidas no final dos anos 60 (RIDENTI, 2000, p.25).

Tendo essa perspectiva em mente, é possível enriquecer ainda mais a interpretação de Rio, Zona Norte. Por um ângulo, a pequena burguesia, mesmo a intelectual, é paternalista e alienada por exemplo, aquela caracterizada pela personagem de Moacyr e seus amigos. Por outro, no desfecho do filme cabe ao violinista - que durante toda a trama postergou a ajuda a Espírito, pois estava muito ocupado com os caprichos do seu meio - resgatar os "três ou quatro sambas" do compositor. O filme termina com a insinuação de que ele quiçá poderá criar uma arte revolucionária, sem no entanto suplantar a possibilidade de cair na estilização, que tanto repudia. As ambiguidades de Moacyr aprofundam seu lastro psicológico: ele próprio é um alterego de Nelson Pereira dos Santos, com quem o diretor se identifica e, ao mesmo tempo, alguém que ele confronta. Dessa maneira, o cineasta joga a responsabilidade de alavancar a "cultura autêntica" para mover a história sobre sua própria classe. Mas também hesita, pois não tem certeza se esse é o caminho certo para a utopia. 0 epílogo condena Moacyr por ter perdido a chance de aprender com o compositor em vida. Contudo, também abre caminho para que ele faça algo com as canções do sambista. Mas além de arroga para sua própria classe um papel transformador, Nelson Perei- 
ra inverte de modo sugestivo a relação entre intelectual e povo, como a alcunha do personagem de Grande Otelo sinaliza: Espírito da Luz Soares é um nome escolhido a dedo, pois na umbanda, o Espírito da Luz é um espírito superior, mais puro, que comanda os espíritos sem luz -, com sua morte agônica, a dar a Moacyr a consciência da urgência dessa operação de resgate e integração (FABRIS, 1994, p.197).

Com Rio, 40 graus e Rio, Zona Norte, ao fazer um retrato crítico sobre a indústria cultural - seja a fonográfica, em termos diegéticos, ou a cinematográfica, no uso da linguagem -, Nelson Pereira estabelece a figura do cineasta engajado, de esquerda, que tornará o cinema uma forma privilegiada de diagnóstico das contradições do capitalismo periférico e, quiçá, de sinalização de caminhos para a utopia, transformando os termos e hierarquias no campo cinematográfico brasileiro.

Os realizadores de cinema até então, tais como Adhemar Gonzaga, Humberto Mauro, Ruy Costa, Luiz de Barros, José Carlos Burle, Alinor Azevedo, Moacyr Fenelon, Alex Viany e Carlos Manga - e mesmo diretores da Vera Cruz, como Alberto Cavalcanti e Lima Barreto -, entre outros, têm cada um a seu modo um objetivo, por assim dizer, nacionalista e comercial, para a produção cinematográfica. Todos almejam que o cinema brasileiro seja capaz de revelar a face que consideram verdadeira do país. Alguns, como Humberto Mauro, Carlos Manga, Cavalcanti e Barreto, com maior conhecimento da técnica cinematográfica clássica do que outros. Entre eles, Moacyr Fenelon, Alinor Azevedo e Carlos Burle, fundadores da Atlântida, mas também Humberto Mauro, ganham relevância ao buscar um retrato digno das classes populares, por vezes estabelecendo aproximações com a imagem cunhada pelo Partido Comunista. Entretanto, não perseguem uma teleologia da história, nem procuram dar vazão ao diálogo entre forma e conteúdo, como o faz Nelson Pereira dos Santos, e tampouco colocar-se no papel de vanguarda. Não que este cineasta não nutrisse ideais nacionalistas, mas seu cinema é fruto 
do projeto de resgatar um "Brasil autêntico", transformando não apenas o campo cinematográfico, mas também as estruturas sociais do país, rumo a uma sociedade mais igualitária e justa. Se os demais buscavam "descobrir" o Brasil, apostando em qualidades que o tornassem distinto como nação e coerente com o status quo vigente, Nelson Pereira procurou em seus primeiros filmes uma "brasilidade" capaz de propiciar a revolução socialista - uma "brasilidade revolucionária", como define Ridenti, que apostava nas possibilidades da revolução brasileira, nacional-democrática ou socialista, que permitiria realizar as potencialidades de um povo e de uma nação (RIDENTI, 2010, p. 10).

Ao unir engajamento político e cinema, Nelson Pereira dos Santos consegue reunir à sua volta jovens também ligados à esquerda, que se tornam expoentes do Cinema Novo, dando continuidade e renovação a suas ideias por meio de um projeto mais ambicioso, em que elas foram a pedra de toque fundamental. Não obstante, o êxito de Nelson Pereira pode compreender-se na medida em que, em pleno pós-Segunda Guerra Mundial - o período democrático de 1945 a 1964 -, é capaz de sintetizar, em sua direção cinematográfica, condições sociais e culturais bem diversas da geração que o antecedeu. 0 diretor paulista nutre-se da efervescência cultural de São Paulo e, posteriormente, do Rio de Janeiro.

\section{N elson Pereira dos Santos e a construção do cineasta engajado}

Nelson Pereira dos Santos nasceu a 22 de outubro de 1928, em São Paulo. Filho caçula de alfaiate, viveu seus primeiros anos no bairro do Brás. Aos domingos, como era costume entre as famílias de classe média, seu grande lazer era passar a tarde no cinema (ALMEIDA, 1995). Aos 13 anos, ele se mudou para o bairro da Vila Mariana e passou a estudar no Colégio do Estado Presidente Roosevelt, instituição de ensino reconhecida na área de humanas, que formou futuros intelectuais de esquerda como 
Francisco Weffort, Fernando Henrique Cardoso e Ênio Silveira, entre outros. Por via de uma célula do Partido Comunista existente no colégio, Nelson inicia sua militância, para a decepção do pai, maçom, e da mãe, católica. À medida que se caminha para o fim do Estado Novo, Nelson entra em contato com a literatura de Jorge Amado, Graciliano Ramos e José Lins do Rêgo, entre outros escritos, e muitos filmes censurados.

Em 1947, ingressa na Faculdade de Direito do Largo do São Francisco e, no ano seguinte, na Escola de Sociologia e Política. Único filho que teve a oportunidade de cursar ensino superior de um total de quatro, seu pai acalentava vê-lo exercer a profissão de advogado. Mas os interesses de Nelson se voltavam cada vez mais para a militância e a expressão artística, ganhando fôlego e potência através do rico cenário cultural devidamente instalado em São Paulo nos anos $1950^{18}$. A partir dos anos 1940, o crescimento industrial sem precedentes da cidade é responsável pela aparição de uma burguesia nascente, interessada em investir no campo cultural. Disto resulta a fundação do MASP - Museu de Arte de São Paulo (1947), do MAM - Museu de Arte Moderna (1948), do TBC - Teatro Brasileiro de Comédias (1948) e da Vera Cruz (1949), além das transformações e crescimento do acervo da Biblioteca Mário de Andrade, para citar apenas alguns exemplos. É na biblioteca que Nelson Pereira lê os clássicos da literatura brasileira e mundial; no MASP, ele participa do grupo teatro amador, capitaneado pelo pintor Aldo Bonadei, e do Clube dos Artistas e Amigos da Arte. Nesses espaços, monta a peça $O$ feijão e o sonho e discute arte, poesia e pintura. Com o fim da ditadura Vargas, emergem diversos cineclubes na cidade, como o do MAM, organizado por Paulo Emílio Salles Gomes, reaberto em 1946. Como relembra Nelson Pereira, foi graças à abertura democrática que ele teve a oportunidade de assistir a filmes de vanguarda, como os de Eisenstein, 
Fritz Lang e René Clair, entre outros. Antes, sua educação cinematográfica era majoritariamente hollywoodiana. Raramente via filmes europeus. Com grupos de amigos, ele discutia tais produções e sua linguagem, enquanto liam o Tratado de realização cinematográfica, de Leon Kuleshov, e as revistas italianas Cinema e Cinema Novo (SALEM, 1987).

$\mathrm{O}$ futuro diretor lapidaria seus conhecimentos em viagem a Paris, em 1949. Com vistas a participar do Festival da Juventude Comunista, em Varsóvia, Polônia, ele decide viajar para a Europa. Comprometendo-se a enviar notícias do exterior para $A$ Gazeta, onde trabalhava, e com a ajuda das economias do pai, embarca com dois amigos num cargueiro. Em Paris, recebem o auxílio de um grupo de intelectuais ligados ao Partido Comunista, como o pintor Carlos Scliar e o físico Mário Schenberg. Scliar, além de hospedar Nelson, prepara uma lista de todos os filmes que ele deveria ver na Cinemateca Francesa. Por meio de Scliar, ele também entra em contato com Rodolfo Nanni, que estudava no Instituto Superior de Estudos Cinematográficos, e com Joris Ivens, documentarista holandês que preconizava filmes de uma estética simples, sem grandes recursos cinematográficos, cujo propósito era poder captar a profundidade do povo (SALEM, 1987). Na capital da França, Nelson também assiste em primeira mão a filmes do Neo-Realismo italiano que ainda não haviam chegado ao Brasil, como Ladrões de bicicleta (1948), de Victorio de Sica. 0 diretor pretendia ficar na Europa por dois anos e estudar cinema por lá, mas no final de 1949, descobre a gravidez de sua namorada e retorna ao Brasil. Em 1950, vive sua primeira experiência no cinema, com Juventude, um filme sobre jovens trabalhadores. No ano seguinte, torna-se assistente de direção de Saci (1953), de Rodolfo Nanni, que acabara de voltar da Europa. Alex Viany e Ruy Santos, que participam da fita, convidam Nelson para passar uma temporada no Rio de Janeiro, onde integra a equipe do filme Agulha no palheiro (1953), que posteriormente Glauber Rocha (2003) definirá como obra seminal do realismo carioca. 
Antes de dirigir um longa-metragem próprio, Nelson participa do filme Balança mais não cai, de Paulo Vanderley (1953), que havia trabalhado em cinejornais da Atlântida e ganhara reconhecimento por Amei um bicheiro (1952). Em meio ao processo de filmagem, Vanderley briga com toda a equipe e, por conta da turbulência, Nelson tem de finalizar o filme sozinho, ainda que não tenha aceitado assinar a direção da obra (SALEM, 1987). Entretanto, dado o incidente, ele perde um aliado importante, Alex Viany, com quem fica sem conversar por alguns anos. Vivendo em condições financeiras precárias, no bairro do Jacarezinho, na Zona Norte do Rio, ele é rebaixado à célula comunista de menor prestígio, na região da Lapa e de Santa Teresa, pois o PCB não via com bons olhos o projeto de Rio, 40 graus, elaborado à revelia das determinações do partido (RIDENTI, 2010, p. 71). Mesmo assim, Nelson continua na então capital do país, formulando o roteiro deste filme, que será sua estreia na direção.

Sem apoio de produtoras, Nelson Pereira consegue verba para realizar este longa-metragem por meio do mesmo sistema de venda de cotas. Beneficia-se também da portaria do governo Vargas que, para incentivar a produção nacional, estipula a isenção de impostos na compra de películas virgens e consegue uma câmera do Instituto Nacional de Cinema Educativo (INCE), emprestada por Humberto Mauro, por intermédio do fotógrafo de cinema Hélio Silva, com quem trabalhara em Agulha no palheiro ${ }^{19}$.

As filmagens foram atribuladas, com períodos de paralisação por conta dos recursos escassos e do mau tempo que inviabi-

19Com Hélio, Nelson fará vários filmes. Além dele, a equipe completa-se com Jece Valadão, que havia feito algumas pontas em filmes da Atlântida, como Amei um bicheiro e Barnabé, tu és meu; Olavo Mendonça, gerente de produção; e Zé Ketti, que atua e compõe a música tema do filme, entre outros. As cerca de nove pessoas que participaram do filme se auto-denominam "Equipe Moacyr Fenelon", em homenagem ao fundador da Atlântida, falecido em 1953. Observa-se assim o reconhecimento daquele diretor, que construíra um estúdio de cinema com recursos parcos e se contrapusera à entrada de Severiano Ribeiro Jr. na Atlântida, por essa equipe de produção independente. 
lizava a captação das tomadas externas, correspondendo a boa parte do conteúdo do filme. Após longos meses de espera, Rio, 40 graus passa pelo crivo da censura e fica pronto para a distribuição, pela Columbia Pictures do Brasil. Mas o longa, que narra um domingo de sol na vida de um grupo de meninos negros pobres que vendem amendoim em pontos turísticos da cidade, não agrada ao chefe do Departamento Federal de Segurança Pública (DFSP). 0 coronel Geraldo de Meneses Cortez proíbe sua distribuição, alegando que o filme apresenta apenas aspectos negativos da então capital brasileira, como a desorganização e miséria, feito com tal habilidade que serve aos interesses políticos do extinto PCB [...] Os meninos que vendem amendoim são vítimas de um rapaz que extorque dinheiro [...]. Tudo isso não existe (Diário Carioca, 30/09/1955, apud Salem, 1987, p. 114). Para completar, Cortez afirmava que, no Rio, o termômetro jamais havia indicado 40 graus.

O Jornal apresenta outras justificativas do chefe do DFSP: em sua opinião, o retrato jocoso de um coronel, que no filme era deputado federal, é um achincalhe imperdoável à Câmara dos Deputados e, ademais, os diálogos são na pior gíria dos marginais, em substituição à língua vernácula (apud SALEM, 1987, p. 115). Para coroar seus argumentos, ele acusa o filme de blasfêmia, por sobrepor, à imagem do Cristo Redentor, um verso da canção de Zé Ketti, que diz "eu sou o rei dos terreiros" (idem, ibidem).

Episódios semelhantes, em que autoridades reclamaram de um retrato negativo do Rio de Janeiro nos filmes, por causa das cenas de pobreza e da grande quantidade de negros - sendo que este aspecto nem sempre era declarado de forma explícita -, já haviam acontecido com Humberto Mauro, em Favela dos meus amores (SCHVARZMAN, 2004), e Orson Welles, em It's all true (BENAMOU, 2007; STAM, 2008; HIRANO, 2013). Mas agora, apesar das peias autoritárias e racistas de alguns segmentos, representados pelo coronel, o momento era outro, e a proibição ao filme ganhou significados políticos com proporções nacionais 
e internacionais. 0 jornalista de oposição, Pompeu Sousa, que não conhecia Nelson, travou um tenso debate com o coronel do DFSP, apontando os impropérios da censura a Rio, 40 graus, capitaneando uma campanha nacional em favor da liberação do filme, que recebeu o apoio de Jorge Amado, Menotti del Picchia, Gianfrancesco Guarnieri, Salomão Scliar, Sérgio Cardoso, Nelson Gonçalves e, inclusive, José Carlos Burle, Anselmo Duarte, Lima Barreto e Alex Viany, com quem Santos reata então a amizade. Da França, vinham declarações de apoio de Georges Sadoul, Ives Montand e Jacques Prévert, entre outros, que pressionaram as autoridades pela revogação da censura. De fato, o PCB só se juntou à campanha de liberação da fita posteriormente, buscando assumir sua direção por meio seu jornal Imprensa Popular, arregimentação contestada por Nelson Pereira. Em entrevista a Marcelo Ridenti, o diretor contou que naqueles dias, [...] foi escalado para um curso de formação de 30 dias, em local secreto, que o poria fora de circulação pública: "era um sequestro. Sumia, ia para algum lugar e reapareceria um mês depois" (RIDENTI, 2000, p.69-70).

Parte da reação dos intelectuais, artistas e jornalistas encontrava motivação na campanha presidencial para garantir a posse de Juscelino Kubitschek e no medo de um golpe de direita, que ao final não ganhou apoio do Ministro da Guerra, Henrique Teixeira Lott. Mantida a sucessão democrática, o coronel Menezes Cortez sai do comando do DFSP, o que abre caminhos para liberar o filme. Em 31 de dezembro de 1955, a censura é revogada e nas primeiras semanas de lançamento, Rio, 40 graus é um estouro de bilheteria. Conforme conta o próprio diretor, devido à censura, parte do público imaginava que o filme teria cenas picantes e estripulias cênicas.

Rio, 40 graus é então aclamado por parte da crítica. 0 Jornal do Brasil declara ser o longa a mais legítima manifestação artística no cinema. Até Pedro Lima, que na década de 1920 defendeu um cinema apenas com intérpretes brancos, elogia o filme colocan- 
do-o entre os que marcam etapa na nossa indústria, sendo das suas melhores realizações (apud SALEM, 1987, p. 123). A reação da crítica definitivamente acena para outros tempos, de maior abertura à representação dos negros, do subúrbio e de uma estética diversa daquela consagrada por Hollywood. A fita é também selecionada para o Festival Karlovy Vary, na Tchecoslováquia, onde Nelson ganha o prêmio de jovem realizador. Antes, o diretor passa por Paris, onde participa do Encontro Internacional dos Criadores de Filmes, promovido pelo Partido Comunista. Na ocasião, conhece Pierre Kast e Cesare Zavattini, expoentes cineastas engajados e identifica-se com a crítica de Zavattini à autocensura do partido na realização de filmes (SALEM, 1987).

Nelson expressa sua opinião publicamente, na imprensa brasileira, e quando retorna ao país, em agosto de 1956, é repreendido pelo partido, que nessa época estava em crise com as denúncias Nikita Krushev aos genocídios cometidos durante a ditadura de Stálin ${ }^{20}$. 0 cineasta afasta-se do PCB, mas não dos ideais socialistas e comunistas.

Apesar das tensões crescentes no que se refere à essa agremiação política, intelectuais e artistas mantinham com o partido uma relação intricada com custos e benefícios para todos os agentes envolvidos que implica uma relação utópica que não se reduz ao cálculo racional (RIDENTI, 2010, p. 12). Esse tipo de vínculo possibilitou a Nelson beneficiar-se das redes de relações do partido, tanto em suas idas a Paris, quanto na campanha para a liberação do filme, ainda que ele não fosse um leitor assíduo de Marx, o diretor tomou contato com tal teoria marxista lendo a revista Problemas e o Manifesto Comunista para o curso de formação política (RIDENTI, 2000, p. 68). De acordo com Ridenti, Nelson só estudou Marx, O 18 de Brumário, quando foi encarre- 
gado de dar um curso de formação política numa célula de bairro (idem, ibidem).

O cineasta saiu do PCB, conforme justificava, porque prezava acima de tudo a liberdade na criação artística, opondo-se a um tipo de instrumentalização política do cinema, que privilegiava o conteúdo em detrimento da forma. É essa posição que marca a figura do cineasta engajado incorporada por Nelson Pereira dos Santos. Visão similar será adotada e reformulada por parte da geração do Cinema Novo ${ }^{21}$.

\section{A recepção de Rio, Z ona N orte: elogios e críticas a N elson Pereira dos Santos e Grande 0 telo}

Distinguindo-se do filme inaugural de Santos, Rio, Zona Norte mostra de modo mais contundente esse momento de dúvida com relação aos caminhos da revolução, especialmente na hesitação da personagem de Moacyr e no epílogo aberto, deixando o espectador imaginar o que o violinista fará com os sambas de Espírito. Por meio de hesitações e incertezas da trama, Nelson expressa sua decepção com o partido e os perigos de certa instrumentalização da arte.

Financiado com a bilheteria de Rio, 40 graus e com verba da Columbia, Rio, Zona Norte tem algumas sequências realizadas nos estúdios da Flama e artistas de sucesso no elenco, como Grande Otelo e Ângela Maria. Apesar disso, a produção era independen-

21Como interpreta Marcelo Ridenti: "Não se deve, contudo, caricaturar a ação cultural do PCB nos anos 50, significativa em áreas como o cinema (por intermédio de militantes como Alex Viany e Walter da Silveira), o teatro (Guarnieri, Vianinha e o pessoal do Teatro Paulista do Estudante) etc. 0 salto cultural pecebista dos anos 60 vinha sendo lentamente maturado no periodo em que ainda prevalecia o stalinismo. A vida cultural comunista nessa época contava com a participação de intelectuais e artistas significativos" (2000, p. 70). Vale lembrar que Joaquim Pedro de Andrade e Leon Hirszman permaneceriam no PC ao longo de suas carreiras. 
te, como fica indicado nos créditos do filme, encabeçados pelo próprio diretor. Malgrado o apoio técnico, as condições continuam precárias. 0 aluguel do estúdio não é barato e as películas virgens são escassas demais para gastá-las com ensaios do elenco.

Lançado ao final de 1957, o filme tem pouca bilheteria e divide a crítica entre aqueles que atacam a utilização de imagens em estado praticamente bruto e outros que reconhecem o valor do filme frente à produção das chanchadas. Grade Otelo ganha destaque em quase todas as críticas. Na Tribuna da Imprensa, o crítico diz: "Autor instintivo, quase sem treinamento pré-direcional [...], inspirado no Neo-Realismo italiano, mas sem a maturidade dos bons cultores do movimento [...]" (apud Salem, 1987, p.136). Paulo Emílio Salles Gomes escreve uma crítica similar em $O$ Estado de $S$. Paulo, mas reconhece a poesia de uma sequência interpretada por Grande Otelo:

Nelson Pereira dos Santos foi talvez vítima da ilusão de que esse estilo [neo-realista] o dispensasse da necessidade laboriosa de estilização e da procura cuidadosa das convenções mais adequadas aos seus propósitos. Ele simplesmente dispôs numa certa ordem os materiais, quase em estado bruto [...]. Essa fita fracassada contém momentos que, bem estudados, poderão provocar uma tomada de consciência sobre as sutis e misteriosas exigências do cinema e contribuir para o desenvolvimento da tendência neo-realista brasileira. Penso sobretudo na sequência em que o personagem interpretado por Grande Otelo acorda, levanta-se, faz a toalete e recebe a noiva. [...], os movimentos do ator, as palavras que troca com a noiva, o comportamento com a criança e sobretudo a extraordinária presença táctil dos objetos de uso corrente ou da ornamentação humilde do barracão, criam uma harmonia interior e comunicam uma doçura que conferem a essa sequência modesta uma consistência artística rara no cinema brasileiro. (GOMES, 1982 [1958], pp. 351-352)

O crítico de $A$ Noite, ao contrário de Paulo Emílio, considera a montagem do filme de linguagem difícil para o espectador comum, critica a carência de dramaticidade, mas arremata: Rio, 
Zona Norte tem a melhor e mais autêntica qualidade que um filme pode ter: É CINEMA. Em relação a Grande Otelo, este comentarista afirma apenas que está bastante convincente (A Noite, 27/11/1957, p. 3-6). 0 crítico Alberto Shatovsky rechaça o filme, mas elogia o protagonista dizendo: o que se extrai de Rio, Zona Norte é praticamente o personagem e o intérprete Grande Otelo. $O$ personagem válido como figura de um quadro social popular. $O$ intérprete, integrando-se perfeitamente no personagem, numa demonstração cabal de que é um dos mais sensíveis atores brasileiros (apud FABRIS, 1994, p. 198).

O Diário carioca concorda com os que dizem que o filme apresenta deficiências na captação de som e composição de algumas cenas, mas também faz a mais elogiosa dentre as críticas recebidas pelo longa:

Três méritos não podem ser negados ao diretor Nelson Pereira dos Santos, como produtor-argumentista-diretor (portanto o autor do filme), nesta segunda experiência procurando levar para o cinema um tema de sensível correspondência com a realidade carioca: que ele conseguiu dar autenticidade física e psicológica aos tipos que criou; que conseguiu, através de um ritmo propositadamente lento, integrar os personagens do drama narrado no ambiente de pessimismo ao qual reagem com otimismo peculiar aos que estão acostumados a sofrer; e que, elaborando a crônica sofrida de um compositor que só a custo conseguiu sucumbir às circunstâncias adversas que a vida lhe reservou, enfrentou o risco de desagradar a plateia como protagonista, não colocando um galã propício à fácil sensibilização do grande público. [...]. 0 grande ator negro, Otelo, tem nesta interpretação simultaneamente a maior da sua carreira no cinema e a maior interpretação de um ator no cinema brasileiro. Controlado e dócil à direção, mas sobretudo espontâneo e sensível por natureza e devoção, está exato no mínimo detalhe, do gesto à palavra e à expressão. Particularmente nos momentos em que contracena com Jece Valadão ou Paulo Goulart, atores também profissionais como ele, o filme começa a crescer. (Diário Carioca, 21/11/1957, p. 7, grifos meus). 
O primeiro ponto a destacar nessa crítica é a denominação de Nelson Pereira dos Santos como "autor" do filme, termo cunhado pela Nouvelle Vague para designar cineastas que, dentro ou fora da indústria cinematográfica, mantêm, de um filme para outro, uma mise-en-scène própria, ou seja, uma maneira idiossincrática de dispor e enquadrar os elementos em cena. Longe do padrão industrial dos filmes de Hollywood, da Cinédia e da Sonofilmes, em que as funções de diretor, argumentista e produtor são enquadradas em princípios de produtividade na divisão do trabalho, nos filmes de Nelson ele assina todas as etapas, inclusive a montagem. A crítica do Diário também difere das anteriores ao reconhecer que o cineasta optou, por conta e risco, por escalar um não-galã, evitando o uso de um recurso que seria mais propício à fácil sensibilização do grande público. Grande Otelo conquista a simpatia da platéia por meio de outros predicados - em geral, em papéis cômicos - e, aos olhos do cinema do período, seu talento para o drama não era visto como um chamariz de bilheteria. Por fim, o crítico, assim como fizera Paulo Emílio, reconhece uma interpretação de gestual poético do ator principal.

Segundo Fabris, o próprio Nelson Pereira dos Santos destaca o papel fundamental de Grande Otelo, a ponto de atribuir-lhe a parceria na realização do filme (SANTOS apud FABRIS, 1998, p. 198). Em entrevista, o diretor afirma:

sem ele, Espírito da Luz Soares, por assim dizer, não existiria, [...] sem a sua compreensão desse personagem, profundamente humano, o filme não valeria nada. Otelo soube dar os necessários e indispensáveis matizes ao drama de um homem que sofre e que é ao mesmo tempo, a expressão da alegria de seu povo (idem, ibidem)

Otelo faz um papel singular em Rio, Zona Norte, distanciando-se de estereótipos das chanchadas e assumindo novas dimensões com relação a Também somos irmãos e Amei um bicheiro. Como mencionado outrora, ele é pai, padrinho e homem honesto, de 
maturidade inexistente em seus papéis anteriores. No decorrer da trama, o ator modula alegria e tristeza, esperança e decepção em gestos sutis, num crescendo de enorme dramaticidade. A personagem de homem maduro, entretanto, não desbanca sua persona de moleque malandro e Otelo continua, até a década de 1960, fazendo papéis que reforçam esse tipo nas chanchadas, ao lado de Ankito. De modo análogo, seu reconhecimento pelo Cinema Novo, em 1968, virá por meio de uma persona similar, reatualizada em Macunaíma.

A destreza de Grande Otelo na interpretação de Espírito se torna mais marcante quando lembramos que o ator só foi conhecer o samba carioca aos 17 anos, momento em que passou a atuar como malandro e sambista nas peças da Companhia de Teatro de Revistas de Jardel Jércolis. Conforme é possível ver nas críticas da época (DOURADO, 2005; CABRAL, 2005; BRITO, 2011; HIRANO, 2013), levou cerca de dois anos para ele conseguir arrancar palmas da plateia com uma interpretação convincente, após treinos diuturnos e aprendizagem na boemia da Lapa, especialmente no Elite Clube, casa famosa de gafieira no centro do Rio de Janeiro. Não era para menos, Grande Otelo nasceu em Minas Gerais e passou a infância e adolescência na cidade de São Paulo, sob a tutela de famílias brancas abastadas. Na infância, quando fez sucesso na Companhia Negra de Revistas, foi interpretando monólogos e árias - e não como sambista.

Esses dados biográficos de Grande Otelo são importantes ao revelar não apenas o esmero do ator como cantor de óperas e declamador de densos monólogos aos nove anos de idade, desbancando possíveis visões reducionistas, mas também ao mostrar que sua singularidade está em observar, aprender e encarnar de forma sem igual outros modos de vida diferentes do seu. 


\title{
C onsiderações finais
}

As críticas de jornais de Rio, Zona Norte coroam a interpretação de Grande Otelo, que desponta como um dos maiores intérpretes do Brasil. Mas depois desse filme, há um grande lapso temporal para o ator ser aclamado novamente. A dívida acumulada coloca Nelson em difícil situação e o diretor vê-se obrigado a retomar o emprego de jornalista de segundo escalão e fazer documentários encomendados. No entanto, esse filme e, especialmente, Rio, 40 graus são reconhecidos pela geração de jovens que dá início ao Cinema Novo. Carlos Diegues (2001) afirma que foi assistindo a Rio, 40 graus que ele vislumbrou a possibilidade de ser cineasta. Glauber Rocha é mais enfático, na Revisão crítica do cinema brasileiro:

\begin{abstract}
Assim como eu, naquele tempo tateando a crítica, despertei violentamente do ceticismo e me decidi a ser diretor de cinema brasileiro nos momentos que estava assistindo Rio, 40 graus, garanto que oitenta por cento dos novos cineastas brasileiros sentiram o mesmo impacto. Naquela época não conhecíamos Humberto Mauro; havia dignidade em Nelson Pereira dos Santos; Cavalcanti nos parecia uma estrela distante; Lima Barreto um monstro agressivo e mentiroso; Mário Peixoto um mito. (ROCHA, 2003a, p.103-104)
\end{abstract}

Glauber considerava Rio, Zona Norte mais profundo, tecendo elogios à atuação de Grande Otelo no filme:

Rio, Zona Norte é dissonante no conjunto, não tem a forma definida de Rio, 40 graus. Mas aí a 'dialética de jornal' evolui para uma penetração mais aguda: o homem brasileiro deixava de ser uma categoria puramente de classe. Homem de classe, mas homem com implicações existenciais. 'Espírito', o sambista de Rio, Zona Norte, vivido excepcionalmente por Grande Otelo, é a pobreza, a ingenuidade, o servilismo e o talento dos negros sambistas da Zona Norte; sonhadores e românticos, sofridos e esmagados pelo império do rádio. (idem, ibidem, p.108) 
Mas se Rio, Zona Norte ainda dialoga com a cinematografia brasileira anterior, a nova geração tem a liberdade de experimentar outros caminhos, negando qualquer relação com as chanchadas e demais projetos de cinema industrial no Brasil. Artistas vinculados aos musicais carnavalescos e à Vera Cruz, como Grande Otelo, Oscarito, Ankito, Eliana Macedo, Vera Regina, Anselmo Duarte e Ruth de Souza, entre outros, não mais serão escalados por essa nova geração. Apesar dos elogios de Glauber Rocha, Otelo vivencia um período de ocaso no auge do cinemanovismo. Uma nova leva de atores negros, com interpretações diferentes de Grande Otelo, entra em cena: Antonio Pitanga, Zózimo Bulbul, Eliezer Gomes e Luíza Maranhão, entre outros, ganham as telas de cinema, não só como afirmações de uma beleza negra, mas simbolizando uma estética de engajamento na primeira fase do Cinema Novo.

\section{REFERÊN C IAS BIBLIO GRÁFIC AS}

ALMEIDA, Heloísa Buarque. Cinema em São Paulo:hábitos e representação do público (anos 40 /50 e 90). Dissertação de Mestrado, São Paulo, PPGAS/ FFLCH/USP, 1995.

ARRUDA, Maria Arminda do Nascimento. Metrópole e Cultura: São Paulo no meio século XX. Bauru: Edusc, 2001.

AUGUSTO, Sérgio. Este mundo é um pandeiro. São Paulo: Companhia das Letras, 2005.

AUMONT, Jaques e MARIE, Michel. Dicionário Teórico e crítico de cinema. São Paulo: Papirus, 2003.

AUTRAN, Arthur. o Pensamento Industrial Cinematográfico Brasileiro. Campinas: Tese de Doutorado, Unicamp, 2004.

BARON, Cynthia e CARNICKE, Sharon Marie. Reframing screen performance. Michigan, University of Michigan Press, 2008.

BAZIN, André. Orson Welles. Rio de Janeiro, JZE, 2006.

BENAMOU, Catherine L. It's All True: Orson Welles's Pan-American Odyssey. Los Angeles: University of California Press, 2007. 
BENJAMIN, Walter. A obra de arte na era de sua reprodutibilidade técnica. In:__ Obras escolhidas: Magia e técnica, arte e política. São Paulo, Editora Brasiliense, 1987.

BHABHA, Homi. O local da cultura. Belo Horizonte: Editora UFMG, 2007.

BORDWELL, David. A Arte do cinema: uma introdução. São Paulo, Edusp e Editora da Unicamp, 2013.

BRITO, Deise Santos. Um ator de fronteira: uma análise da trajetória do ator Grande Otelo no teatro de revista brasileiro entre as décadas de 20 e 40. São Paulo: Universidade de São Paulo, Escola de Comunicação e Artes, Mestrado em Artes Cênicas, 2011.

CABRAL, Sérgio. Grande Otelo: uma biografia. São Paulo: 34, 2007.

CANDIDO, Antonio. Dialética da malandragem. In:__ 0 discurso e a cidade. Rio Janeiro: Duas cidades, 1993: 19-54

CARVALHO, Noel dos Santos. Cinema e representação racial: o cinema negro de Zózimo Bulbul. (Tese de Doutorado em Sociologia), Faculdade de Filosofia, Letras e Ciências Sociais, Universidade de São Paulo, 2005.

COHAN, Steven. Hollywood Musicals. New York: Routledge, 2002.

DAMATTA, Roberto. Carnavais, Malandros e Heróis. Rio de Janeiro, Rocco, 1997.

RIO Zona Norte, Diário Carioca, Rio de Janeiro, 21 de nov. 1957.

DIEGUES, Cacá “A vocação cinematográfica no Brasil”. Entrevista com Cacá Diegues in: Revista Continental, 01/04/2001. Disponível em <http://www. revistacontinente.com.br/index.php/component/content/article/139.html>. Consultado em 04/04/2013.

DILLON, Josephine. Modern acting: a guide for stage, screen and radio. New York, Prentice-Hall, 1940.

DOURADO, Ana Karicia Machado. Fazer rir fazer chorar: a arte de Grade Otelo. São Paulo: Dissertação de mestrado em História, Universidade de São Paulo, 2005.

DYER, Richard. White: Essays on race and culture. Londres: Routledge, 1997.

FABRIS, Mariarosaria. Nelson Pereira dos Santos: um olhar neo-realista. São Paulo: Edusp, 1994.

FELLINI, Federico. Abismo de um sonho. Itália, Continental, DVD, 1952.

GALVÃO, Maria Rita. Burguesia e Cinema: o caso da Vera Cruz. Rio de Janeiro: Civilização Brasileira, 1981. 
GOMES, Paulo Emílio Salles. Crítica de cinema no suplemento literário vol. I e II. Rio de Jaeneiro: Paz e Terra, 1982.

HALL, Stuart (org.). Representation: cultural representation and signifying practices. Londres, Sage, 1997.

HIRANO, Luis Felipe Kojima. 0 imaginário da branquitude à luz da trajetória de Grande Otelo: raça, persona e estereótipo em sua perfomance artística. Afro-Ásia, Salvador , n. 48, 2013a. Disponível: <http://www.scielo. $\mathrm{br} / \mathrm{scielo}$.php?script=sci_arttext\&pid=S0002-05912013000200003\&lng= en\&nrm=iso>. Acesso: 02 dez. 2015. http://dx.doi.org/10.1590/S000205912013000200003.

HIRANO, Luis Felipe Kojima. Uma interpretação do cinema brasileiro através de Grande Otelo: raça, corpo e gênero em sua performance cinematográfica (1917-1993). 2013b. Tese (Doutorado em Antropologia Social) - Faculdade de Filosofia, Letras e Ciências Humanas, Universidade de São Paulo, São Paulo, 2013. Disponível em: <http://www.teses.usp.br/teses/disponiveis/8/8134/tde-14112013-122614/>. Acesso em: 2015-02-02.

KULESHOV, Lev. Kuleshov on film: writings of Lev Kuleshov. Los Angeles, University of California Press,1974.

MATTOS, Carlos Alberto. Cacá Diegues fala sobre os cinco filmes que são faróis de carreira. Disponível em <http://www.carlosdiegues.com.br/destaques_integra.asp?idA=122>. Consultado em 04/04/2013.

MCDONALD, Paul. Film acting. In: HILL, John e GIBSON, Pamela Church. The Oxford Guide to Film Studies. Oxford, Oxford University Press, 2008.

METZ, Christian. A significação no cinema. São Paulo, Perspectiva, 2010.

PONTES, Heloisa. Intérpretes da metrópole. São Paulo: Edusp, 2011.

RIDENTI, Marcelo. Brasilidade revolucionária. São Paulo: Editora Unesp, 2010.

RIDENTI, Marcelo. Em busca do povo brasileiro: artistas da revolução, do CPC à era da TV. Rio de Janeiro: Record, 2000.

ROCHA, Glauber. Revisão crítica do cinema brasileiro. São Paulo: Cosac Naify, 2003 [1963].

SALEM, Helena. Nelson Pereira dos Santos: o sonho possível do cinema brasileiro. Rio de Janeiro: Nova Fronteira, 1987.

SCHVARZMAN, Sheila. Humberto Mauro e as imagens do Brasil. São Paulo: Editora Unesp, 2004. 
SOUZA, Ruth de, Depoimento para posteridade no Museu da Imagem e do Som, Rio de Janeiro, 27 jun. 1979, entrevista concedida para Neuza Amaral, Jacira Silva, Rui Silva, Alex Viany, José Carlos Monteiro, Salviano Cavalcanti de Paiva.

STAM, Robert. Multiculturalismo tropical. São Paulo: Edusp, 2008.

VANDERLEY, Paulo. Balança mais não cai. Rio de Janeiro, Cinedistri, $35 \mathrm{~mm}$, BP, 90min. 1952.

Data de Recebimento: 12 de dezembro de 2014

Data de Aprovação: 30 de dezembro de 2014 